\title{
MANAGEMENT STRATEGY OF NINO CONI SANTANA NATIONAL PARK AT TUTUALA VILLAGE, TUTUALA SUB-DISTRICK, LAUTEM DISTRCK, TOMOR-LESTE
}

\author{
Edelmiro Jose De Deus ${ }^{\left.1^{*}\right)}$,Wayan Windia ${ }^{2)}$, Ida Ayu Astarini ${ }^{3)}$, \\ ${ }^{1 *}$ Kementerian Perdagangan, Industri, dan Lingkungan Hidup Timor Leste \\ ${ }^{2)}$ Fakultas Pertanian, Universitas Udayana \\ ${ }^{3}$ Fakultas Biologi, Universitas Udayana \\ *Email: dedelmirojose@yahoo.com
}

\begin{abstract}
Nino Coni Santana National Park had been suffered by illegal logging, and other activities that are not environmenknowleage. Lack of a security and knowledgeabout forest also contributeto increasethe damage of Nino Coni Santana National Park (1)The purpose of this research is to determine management strategy of Nino Coni National Park due to illegal logging in the area Tutuala and Mehara village at Tutuala sub-district,Lautem district, Timor Leste and determine management strategy of Nino Coni Santana National Park. Public perception obtained through questionnaires with purpose sampling method. The formula of management strategy for the damage in Nino Coni Santana National park use SWOT analysis to identify internal and external factors. The level of damage known by identifiy thearea due damaged by illegal logging.(2) The results showed that the damage by illegal logging at Nino Coni Santana national park caused because people are not involved in management of Nino Coni Santana National Park. The problems are illegal logging, encroachment,of forest, slash the wood harting wild animals, lack organization,andillegal grazing.(3) The management strategy of Nino Coni Santana National Park based on local culture, the establishment of a special UPTD that manage Coni Nino Santana forests, HKM and tourism programs, public development programs and cooperation of local people in order to utilize, surveillance and patrolling forests. In order to develop local knowledge as a base inNino Coni Santana National park, through HKM and tourism, Public socialization about the importance of forest. To measure the success of this management,should do monitoring, controlling andevaluation periodically by the government and involve the local people around Nino Cono Santana National Park.
\end{abstract}

Keywords : Damag; Management Strategy Coni Nino Santana; of Nino Coni SantanaNational Park; People Society

\section{PENDAHULUAN}

Timor-Leste sebagai negara yang baru restorasi pada tahun 2002 masih harus mengejar ketinggalan dari negara-negara lain. Dengan membangun bisa membawa negara ini lepas dari ketertinggalannya. Salah satu sektor vital yang perlu diperhatikan oleh pemerintah Timor-Leste adalah kawasan hutan. Taman Nasional Nino Coni Santana merupakan hutan lindung konservasi, penetapannya berdasarkan Peraturan Pemerintah No.8/2007 tentang berdirinya TNNCS.

Pertumbuhan sektor kehutanan yang sangat pesat menjadi akibat kegiatan eksploitasi yang tidak terkendali dan dilakukan secara masif tanpa memperhatikan aspek kelestarian dan berkelanjutan. Kecenderungan masyarakat yang memanfaatkan hasil hutan yang dititik beratkan pada kepentingan ekonomi melalui praktek illegal logging dengan mengesampingkan fungsi sosial maupun lingkungan.

Hilangnya pemahaman masyarakat terhadap kearifan lokal setempat terhadap bagaimana memperlakukan lingkungan pada akhirnya menimbulkan kesenjangan sosial di tengah masyarakat. Taman Nasional Nino Coni Santana merupakan ivestasi dari tipe ekosistem hutan tropis yang berada pada daratan rendah dan daratan tinggi Pulau Timor-Leste. Di sana terdapat flora endemik pulau Timoe-Leste seperti cendana, kayu merah,dan fauna seperti rusa Timor-Leste. Kawasan Taman Nasional Nino Coni Santana telah mengalami kerusakan serius dan penurunan hutan yang di akibatkan oleh illegal logging serta kegiatan lain yang tidak berwawasan lingkungan yang disinyalir akibat kemiskinan. Kurangnya koordinasi antara pemerintah dan masyarakat sekitar kawasan Taman Nasional Nino Coni Santana, mengakibatkan upaya konservasi yang dilaksanakan pemerintah tidak berjalan secara optimal.

Tujuan yang ingin dicapai dalam penelitian ini adalah untuk mengetahui kerusakan Taman Nasional Nino Coni Santana dari segi luasan akibat illegal logging di wilayah Desa Tutuala dan Mehara Kecamatan Tutuala Kabupaten Lautem TimorLeste.Disamping itu untuk menentukan strategi pengelolaan secara berkelanjutan Taman Nasional Nino Coni Santana. Adapun ruang lingkup penelitian ini adalah akan menkaji presepsi masyarakat sekitar Hutan Nasional Nino Coni Santana terhadap 19 
keberadaan Taman Nasional Nino Coni Santana dan kerusakan hutan akibat illegal logging di Desa Tutuala dan Mehara, yang rusak akibat illegal logging pada Taman Nasional Nino Coni Santana di Desa Tutuala dan Mehara.

Sampel penelitian ini adalah masyarakat Desa Tutuala dan Mehara yang tinggal disekitar kawasan taman hutan. Sampel diambil secara purposivesampling.Sumber data penelitian ini adalah data primer yaitu data langsung dari sumber sumber pertama yaitu masyarakat Desa Tutuala dan Mehara.Sumber yang lain adalah data sekunder yaitu data dari instansi pemerintahan yang terkait berupa dokumen, referensi, laporan kegiatan dan lain sebagainya.Pengumpulan data dilakukan dengan pemberian kuisioner dan wawancara terstruktur dengan 20 kepala keluarga di dua Desa Kecamatan Tutuala.Untuk mengetahui kerusakan Taman Nasional Nino Coni Santana akibat illegal logging dilakukan dengan carasurvey pada daerah yang mengalami kerusakan dengan melakukan pendokumentasian. Untuk menentukan strategi yang akan menjadi acuan atau masukan terhadap stakeholder adalah dengan mengunakan analisis SWOT. Analisis SWOT digunakan untuk menganalisa faktor internal dan eksternal yang berpengaruh terhadap strategi pengelolaan Taman Nasional Nino Coni Santana

Kawasan Taman Nasional Nino Coni Santana dalam kondisi yang tidak baik. Hal ini tidak terlepas dari permasalahan yang dihadapi dalam pengelolaan Taman Nino Coni Santana selama ini seperti illegal logging, perburuan satwa liar,penggembalaan liar dan perambahan yang dilakukan oleh masyarakat sekitar kawasan Taman Nasional Nino Coni Santana. Manfaat yang diberikan oleh Taman Nasional Nino Coni Santana menurut responden adalah sebagai sumber air, sumber kayu bakar dan sumber hasil hutan non kayu seperti buah. Pengelolaan Taman Nasional Nino Coni Santana belum berjalan optimal akibat kurangnya koordinasi antar stakeholder serta kurangnya penyuluhan akan pentingnya kawasan hutan, masyarakat kurang dilibatkan dalam pengelolaan Taman Nasional Nino Coni Santana.

Masyarakat sekitar hutan berhak mengetahui dan dilibatkan dalam setiap rencana pengambilan keputusan tentang program dan kebijakan yang berkaitan dengan kawasan hutan yang secara langsung akan menpengaruhi kehidupan mereka. Kearifan lokal dalam masyarakat sekitar kawasan Taman Nasional Nino Coni Santana dilakukan melalui ritual keagamaan di dalam hutan, tidak menebang jenis pohon yang dianggap bisa menyimpan air serta tidak berbuat sembarangan dalam kawasan hutan. Minimnya pengawasan dan juga jumlah aparat yang bertugas di kawasan Taman Nasional Nino Coni Santana mengakibatkan terjadinya kerusakan hutan.
Penyebab masih terjadinya illegal logging dalam kawasan Taman Nasional Nino Coni Santana adalah kayu yang bernilai ekonomi tinggi khususnya jenis kayu jati.Pencurian kayu diakibatkan oleh tingkat pendapatan perkapita dan sumberdaya masyarakat sekitar hutan rendah. Permasalahan yang dihadapi Taman Nasional Nino Coni Santana di Desa Tutuala dan Mehara adalah aspek sosial ekonomi yang meliputi :illegal logging, perambahan hutan, pengambilan kayu bakar, budaya tebas bakar, penataan kawasan, organisasi yang belum optimal, perburuan satwa liar dan penggembalaan liar.Kerusakan pada kawasan Taman Nasional Nino Coni Santana yang disebabkan oleh kegiatan illegal logging, dapat dihindari dengan pengelolaan Taman Nasional Nino Coni Santana berdasarkan kearifan lokal masyarakat setempat, pembentukan UPTD khusus yang mengelolah Taman Nino Coni Santana dalam rangka peningkatan pelayanan, pengelolaan, penjagaan dan pelestarian kawasan Nino Coni Santaana.Disamping itu, perlu ada program HKM dan pariwisata dengan melibatkan masyarakat Taman Nasional Nino Coni Santana, program pembinaan masyarakat, dan kerjasama dengan masyarakat setempat dalam rangka pemanfaatan, pengawasan dan pengamanan kawasan Taman Nasional Nino Coni Santana. Perlumenbentuk UPTD khusus untuk mengelolah Taman Nasional Nino Coni Santana dengan melibatkan stakeholder.Pihak pengelola perlu memberdayakan masyarakat sekitar Taman Nasional Nino Coni melalui program HKM dan pariwisata.Sosialisasi berupa penyuluhan tentang pentingnya kawasan hutan perlu ditingkatkan lagi. Untuk dapat mengukur keberhasilan pengelolaan Taman Nino Coni Santana kedepan perlu kegiatan monitoring, kontrol dan evaluasi dilakukan secara berkala oleh pemerintah, dengan melibatkan masyarakat di sekitar Taman Nasional Nino Coni santan.

Di dalam hutan tersebut terdapat tiga aspek penting yaitu pola bagaimana manusia memanfaatkan alam, tempat penting untuk ritual tradisional dan tempat-tempat bersejarah. Selain itu Taman Nino Coni Santana merupakan habitat dan konservasi populasi burung endemik yang langka. Antara lain 19 jenis burung endemic yakni 1). kakatua jambul kuning (Cacatua sulphurea) 2). merpati hijau (Trerong psittaceus) 3). merpati atau pombo (Dusula cineracia). 4). burung pipit (Paddafoscota) yang terancam punah speciesnya.

Taman Nasional terletak di Kecamatan Tutuala, Kabupaten Lautem Timor-Leste. Hutan ini memiliki fungsi perlindungan terhadap empat sumber mata air, Danau Ilalaru, Pualu Jaco, obyek wisata yang berada di sekitar hutan ini. Selain fungsi tersebut taman hutan ini merupakan kawasan pelestarian keanekaragaman hayati. Konsekuesinya, hilangnya hutan karena terjadinya alih fungsi lahan, kebakaran hutan, serta perkembangan yang 
eksploitatif dan tidak terkontrol. Kecendrungan masyarakat yang memanfaatkan hasil hutan yang dititik beratkan pada kepentingan ekonomi melalui praktek illegal logging dengan mengesampingkan fungsi sosial maupun lingkungan telah menjadi hutan kehilangan fungsi pokoknya.

Artikel ini membahas tentang identifikasi permasalahan tersebut di atas, maka dapat dirumuskan permasalahan penelitian tentang bagaimana strategi pengelolaan kawasan Taman Nasional Nino Coni Santana. Tujuan penelitian ini untuk menentukan strategi pengelolaan Taman Nasional Nino Coni Santana.

Menurut Andrews (1980), strategi adalah kekuatan motivasi untuk stakeholders, manajer, karyawan, konsumen, komunitas, pemerintah, dan sebagainya, yang baik secara langsung maupun tidak langsung menerima keuntungan atau biaya yang ditimbulkan oleh semua tindakan yang dilakukan oleh perusahaan. Pemahaman yang baik mengenai konsep strategi dan konsep- konsep lain yang berkaitan, sangat menentukan suksesnya strategi yang disusun Taman Nasional Nino Coni Santana merupakan salah satu asset yang dimiliki oleh Kabupaten Lautem yang manfaatnya dapat dirasakan oleh banyak pihak, dan bukan hanya satu pihak saja. Oleh karena itu dalam pengelolaannya harus memperhatikan strategi yang tepat dimana harus memperhatikan stakeholdersyang secara langsung maupun tidak langsung menerima keuntungan atau biaya yang ditimbulkan dalam pengelolaan sumberdaya alam di kawasan tersebut.

Peran serta masyarakat dalam pengelolaan hutan menurut UU Kehutanan No. 41 tahun 1999 pasal 68 meliputi: 1) Masyarakat berhak menikmati kualitas lingkungan hidup yang dihasilkan hutan 2) Masyarakat dapat memanfaatkan hutan dan hasil hutan sesuai dengan peraturan yang berlaku, mengetahui rencana peruntukan hutan, pemanfaatan hasil hutan, memberi informasi, saran, serta pertimbangan dalam pembangunan kehutanan dan melakukan pengawasan, 3) Berhak memperoleh kompensasi karena hilangnya akses atau hak atas tanah miliknya. Dalam pengelolaan hutan, isu pokok yang sering muncul adalah adanya gangguan terhadap hutan terutama pencurian kayu bakar. Faktor-faktor yang menyebabkan gangguan terhadap hutan adalah sebagai berikut. 1.Pendapatan yang diperoleh relatif tinggi dan caranya mudah 2.Rantai pemasaran yang rendah 3.Keterbukaan wilayah yang tinggi 4.Alternatif lapangan pekerjaan yang terbatas

Hutan merupakan lahan yang di dalamnya terdiri dari berbagai tumbuhan yang membentuk suatu ekosistim dan saling ketergantungan.Fungsi hutan tidak dapat dilepaskan dari pengaruh manusia dalam memanipulasi penggunaan dan pemanfaatan sumber daya hutan untuk kepentingan kehidupan dan lingkungan. Hutan sebagai sumber daya juga menentukan masyarakat untuk pengelolaannya
(Awing, 2004)

Secara tradisi pada umumnya masyarakat sekitar hutan memiliki mata pencaharian dengan memanfaatkan produk-produk hutan, baik kayu maupun bukan kayu karena dengan meningkatnya jumlah kepadatan penduduk di dalam dan sekitar kawasan hutan, kondisi kualitas sosial penduduk di sekitar hutan secara umum menurun (Daud, 2010).

Menurut Wollenberg, et al. (2009) mengemukakan penyebab kerusakan oleh masyarakat sekitar sebagai berikut.

1 Masyarakat yang tinggal di hutan merupakan salah satu kelompok miskin

2 Hutan merupakan sumber daya penting bagi orang miskin

3 Hutan menyediakan pelayanan ekosistem yang mendasar bagi penghidupan dan kesejahteraan penduduk di sekitar hutan, khususnya mereka yang miskin.

4 Lahan atau semua kawasan hutan dikuasai oleh negara

5 Sumber daya yang dipanen, ditambang atau dimanfaatkan dari kawasan hutan bernilai sangat besar.

\section{METODOLOGI}

Penelitian mengunakan metode kualitatif diawali dengan pengamatan (survey) dan wawancara mendalam (deep interview). Informasi juga diperoleh melalui wawancara dengan penyebaran kuisioner dan dokumentasi. Penyajian data disajikan dalam bentuk tabulasi maupun naratif. Alat analisis yang digunakan adalah SWOT untuk menentukan strategi pengelolaan Taman Nasional Nino Coni Santana. Penelitian ini dapat merumuskan kebijakan dan program-program berdasarkan kondisi internal kekuatan (strenght) dan kelemahan, (weaknesses) yang memeliki situasi eksternal peluang (opportunity) dan ancaman (threats)Penyajian hasil analisis data akan disajikan secara deskriptif kualitatif.

\section{HASIL DAN PEMBAHASAN}

\subsection{Kondisi Taman Nasional Nino Coni Santana}

Ketergantungan masyarakat sekitar Taman Nasional Nino Coni Santana meliputi penyedian kayu bakar dan pemanfaatan jenis hasil hutan non kayu berupa buah kemiridan pakan ternak.Fungsi lain bagi masyarakat sekitar kawasan Taman Nasional Nino Coni Santana yang bersifat non ekonomi adalah pemanfaatannya sebagai sumber air untuk pemenuhan kebetuhan sehari- hari (mandi, cuci dan minum), tempat minum ternak bahkan sebagai cadangan air untuk lahan pertanian sekitar 
Kawasan Taman Nasional Nino Coni Santana. Bahkan sampai di daerah hulu (Desa Mehara) dimana Kawasan Nasional Nino Coni Santana merupakan daerah tangkapan air sekaligus penyimpan air(Upa,et al, 1999).

Permasalahan yang timbul dihadapi dalam pengelolaan Taman Nasional Nino Coni Santana adalah Ilegal logging, perambahan hutan, pengambilan kayu bakar, budaya tebas bakar, penataan kawasan, organisasi belum optimal, perburuan satua liar dan pemgembalaan liar.Melalui pemaparan dalam bentuk imformasi, artinya bahwa hasil penelitian ini di paparkan dalam interpretasi sesuai teori dan modal penelitian berlaku umum, serta secara formal dalam bentuk tabel, gambar, bagan, serta informasi dalam bentuk narasi. Hasil penelitian ini diharapkan dapat memberikan gambaran yang lebih jelas dan mendalam tentang tujuan penelitian yang dilakukan.
7. Terdapat organisasi dan tokoh masyarakat yang menpunyai perhatian terhadap pelestarian hutan

B. Kelemahan (Weaknesses)

1. Pengelolaan Taman Nasionan Nino Coni Santana belum optimal

2. Koordinasi antar stakeholder belum berjalan optimal

3. Batas/Zonasi kawasan belum jelas

4. Sarana dan prasarana belum memadai

5. Hutan di pandang sebagai sumber ekonomi

6. Jumlah staf pengawasan TNNCS yang sangat minim

C. Indentifikasi Eksternal

D. Peluang (Opportunities)

1. Status kawasan sebagai taman Nasional Nino Coni Santana

2. Pelung investasi untuk wisata alam dan hutan pendidikan di kawasan Taman

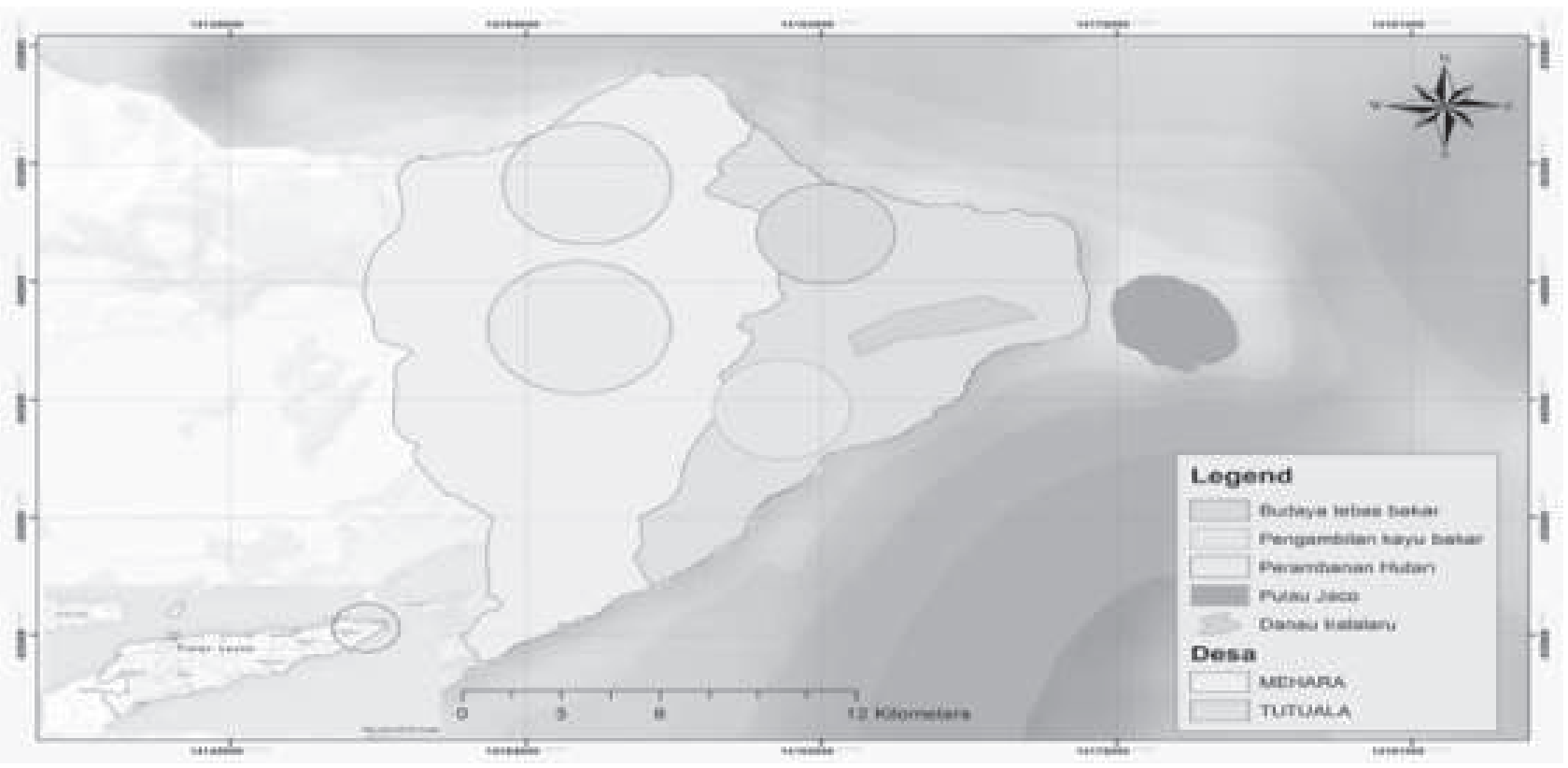

Gambar 1.Peta Lokasi Penelitian

\subsection{Indentifikasi Faktor Internal}

A. Kekuatan (Strenght)

1. Taman Nino Coni Santana sebagai sumber ekonomi dan ekologi

2. Aturan pengelolaan Taman Nino Coni Santana sudah dituangkan dalam PP No. 8 tahun 2007 tentang pengelolaan kawasan lindung.

3. Letak kawasan Taman Nasional Nino Cani Santana yang sangat strategi

4. Potensi kawasan Taman Nasional Nino Cani Santana sangat besar (Flora, Fauna, dan Parawisata)

5. Taman Nasional Nino Coni Santana merupakan cathment area

6. Adanya kearifan lokak untuk akses masuk Taman Nasional Nino Coni Santana
Nasional Nino Coni Santana

3. Alokasi dana pengelolaan Taman Nasional Nino Coni Santana

E. Ancaman (Treahts)

1. Pertambahan jumlah penduduk di sekitar Kawasan Taman Nasional Nino Coni Santana.

2. Tidak ada akses jalan utama dalam kawasan Taman Nasional Nino Coni Santana untuk illegal logging.

3. Sumberdaya masyarakat sekitar kawasan Taman Nasional Nino Coni Santana tergolong rendah.

4. Pengetahuan akan budaya menjaga hutan di kalangan kaum muda mulai pudar.

5. Masyarakat masih mengunakan kayu sebagai bahan bakar utama.

6. Hutan di pandang sebagai Sumber Ekonomi. 
7. Budaya tebas bakar masih di lakukan masyarakat.

8. Gangguan hutan berupa illegal logging, perambahan hutan, penggembalaan ternak dan perburuan liar.

\subsection{Analisis SWOT}

Berdasarkan hasil analisis faktor internal dan external yang menpengaruhi pengelolaan Taman Nasional Nino Coni Santana adalah beberapa faktor yang akan dianalisis untuk mencapai sebuah strategi pengelolaan Taman Nasional Nino Coni Santana.

Tabel 1. Analisis Faktor Internal

\begin{tabular}{|c|c|c|c|c|}
\hline No & Faktor Internal & Bobot \% & Rating & Skor \\
\hline I & Kekuatan & & & \\
\hline $\begin{array}{l}1 \\
2 \\
3 \\
4 \\
5 \\
6 \\
7\end{array}$ & $\begin{array}{l}\text { Taman Nino Coni Santana sumber ekonomi dan ekologi } \\
\text { Tanaman Nasional Nino coni Santana merupakan kawasan yang dilindugi PP.No } 8 \text { tahun } 2007 \\
\text { Letak Kawasan Nasional Nino Coni Santana yang sangat strategi } \\
\text { Potensi Kawasan Nasional Nino Coni Santana sangat besar flora, fauna dan parawisata } \\
\text { Taman Nasional Nino coni Santana merupakan cathment area } \\
\text { Adanya kearifan untuk akses masuk TNNCS } \\
\text { Terdapat organisasi dan tokoh masyarakat yang menpunyai perhatian terhadap pelestarian hutan } \\
\text { Jumlah skor kekuatan }\end{array}$ & $\begin{array}{l}9 \\
9 \\
8 \\
6 \\
5 \\
6 \\
7 \\
50\end{array}$ & $\begin{array}{l}3 \\
3 \\
3 \\
2 \\
1 \\
2 \\
3\end{array}$ & $\begin{array}{l}27 \\
27 \\
24 \\
12 \\
5 \\
12 \\
21 \\
128\end{array}$ \\
\hline II & Kelemahan & & & \\
\hline $\begin{array}{l}1 \\
2 \\
3 \\
4 \\
5 \\
6\end{array}$ & $\begin{array}{l}\text { Pengelolaan Taman Nasional Nino Coni Santana belum optimal } \\
\text { Koordinasi antara stakeholder belum berjalan optimal } \\
\text { Batas/ zonasi kawasan belum jelas } \\
\text { Sarana dan prasarana belum memadai } \\
\text { Hutan di pandang sebagai sumber ekonomi } \\
\text { Jumlah staf pengawasan TNNCS yang sangat minim } \\
\text { Jumlah skor kelemahan }\end{array}$ & $\begin{array}{l}10 \\
9 \\
8 \\
9 \\
8 \\
7 \\
50\end{array}$ & $\begin{array}{l}-3 \\
-3 \\
-2 \\
-3 \\
-2 \\
-2\end{array}$ & $\begin{array}{l}-30 \\
-27 \\
-16 \\
-27 \\
-16 \\
-14 \\
-130\end{array}$ \\
\hline
\end{tabular}

Keterangan:

1. Bobot diberikan untuk masing-masing elemen sesuai dengan tingkat penting relatif terhadap keberhasilan pencapaian tujuan.

2. Rating untuk kekuatan dan kelemahan, diberikan atas dasar kesepakatan, yakin masing-masing rating 3 untuk kategori sangat bagus: 2 untuk kategori bagus, dan 1 untuk kategori cukup bagus. Sementara itu rating untuk kelemahan diberikan atas dasar kesepakatan, yakni masing-masing rating - 3 untuk kategori sangat buruk; - 2 untuk kategori buruk, dan -1 untuk kategori cukup buruk.

Tabel 2. Analisis faktor eksternal

\begin{tabular}{|c|c|c|c|c|}
\hline No & Faktor Eksternal & Bobot \% & Rating & Skor \\
\hline 1 & Peluang & & & \\
\hline $\begin{array}{l}1 \\
2 \\
3\end{array}$ & $\begin{array}{l}\text { Status kawasan sebagai Taman Nasional } \\
\text { Peluang investasi untuk wisata alam Kawasan Taman Hutan Nasional Nino Coni Santana } \\
\text { Peluang untuk penelitian dan pendidikan } \\
\text { Alokasi dana pengelolaan Taman Hutan Nasional Nino Coni Santana } \\
\text { Jumlah skor peluang }\end{array}$ & $\begin{array}{l}15 \\
15 \\
10 \\
10 \\
50\end{array}$ & $\begin{array}{l}3 \\
3 \\
2 \\
1\end{array}$ & $\begin{array}{c}45 \\
45 \\
20 \\
10 \\
120\end{array}$ \\
\hline II & Ancaman & & & \\
\hline $\begin{array}{l}1 \\
2 \\
3 \\
3 \\
4 \\
5 \\
6 \\
7 \\
8\end{array}$ & $\begin{array}{l}\text { Pertambahan jumlah penduduk di sekitar kawasan Taman Hutan Nasional Nino Coni Santana } \\
\text { Tidak ada akses jalan utama dalam kawasan Taman Hutan Nasional Nino Coni Santana } \\
\text { Sumberdaya manusia sekitar kawasan Taman Hutan Nasional Nino Coni Santana tergolon rendah } \\
\text { Sumberdaya manusia sekitar kawasan Taman Hutan Nasional Nino Coni Santana tergolon rendah } \\
\text { Pengetahuan akan budaya menjaga hutan di kalan kaum muda mulai pudar } \\
\text { Masyarakat masih mengunakan kayu sebagai bahan bakar utama } \\
\text { Hutan di pandang sebagai sumber ekonomi } \\
\text { Budaya tebas bakar masih dilakukan oleh masyarakat } \\
\text { Gangguan hutan berupa illegal logging, perambahan hutan, penggembalaan ternak dan perburuan liar } \\
\text { Jumlah skor tantangan }\end{array}$ & $\begin{array}{l}8 \\
6 \\
7 \\
7 \\
6 \\
6 \\
5 \\
6 \\
6 \\
50\end{array}$ & $\begin{array}{l}-3 \\
-2 \\
-3 \\
-3 \\
-2 \\
-2 \\
-1 \\
-2 \\
-3\end{array}$ & $\begin{array}{l}-24 \\
-12 \\
-21 \\
-21 \\
-12 \\
-14 \\
-5 \\
-12 \\
-18 \\
-118\end{array}$ \\
\hline & Total (Peluang dan Tantangan) & & & 2 \\
\hline
\end{tabular}

-Keterangan:

1. Bobot diberikan untuk masing-masing elemen sesuai dengan tingkat penting relatif terhadap keberhasilan pencapaian tujuan.

2. Rating untuk peluang dan tantangan ditentukan sebagai berikut. Rating peluang dibrikan atas dasar kesepakatan, yakni masing-masing rating 3 untuk ketegori sangat bagus; 2 untuk kategori sangat bagus, dan 1 untuk kategori cukup bagus. Sementara itu rating untuk tantangan diberikan atas dasar kesepakatan, yakni masing-masing rating -3 untuk kategori sangat buruk; -2 untuk kategori buruk, dan -1 untuk kategori cukup buruk. 
Berdasarkan skor dalam analisis faktor internal dan eksternal sebelumnya, maka kesimpulan SWOT penelitian ini dapat digambarkan seperti terlihat pada Gambar 2

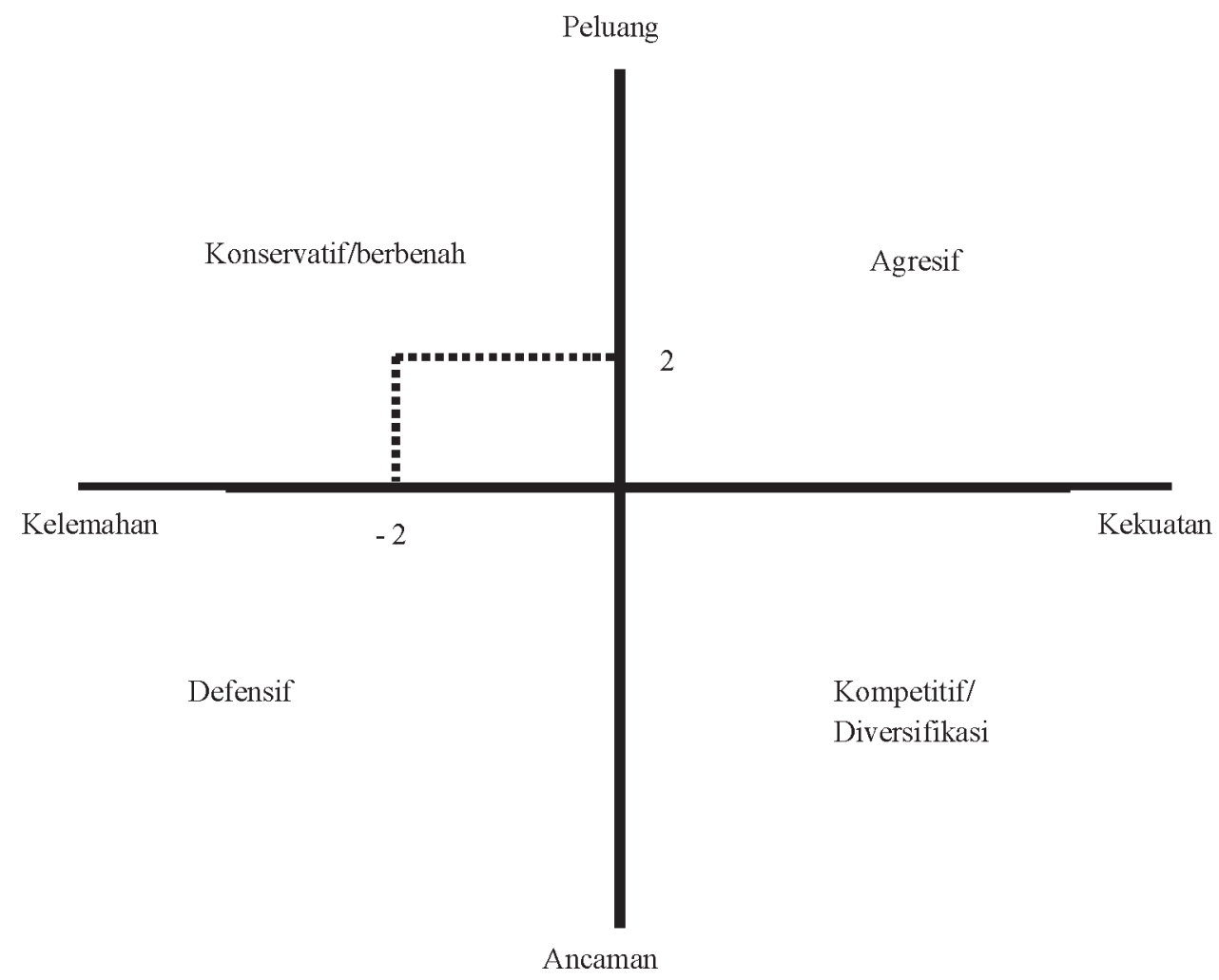

Gambar 2. Diagram analisis SWOT

Hasil analisis SWOT pada Gambar 2, menimpulkan bahwa Pengelolaan Taman Nasional Nino Coni Santana berada dalam kuadran/posisi konservatif, yakni strategi berbenah.

Berdasarkan formulasi strategi SWOT, dapat dirumuskan beberapa strategi pengelolaan di kawasan Taman Nasional Nino Coni Santana, sesuai dengan posisi/kuadran pada diagram SWOT yang berada pada strategi berbenah. Strategi tersebut dapat dirumuskan dalam kombinasi antara peluang (opportunities) dan kelemahan (weaknesses) atau Strategi WO (weaknesses-opportunities) yang dapat dirumuskan sebagai berikut:

1. Pengelolan Taman Nino Coni Santana hendaknya berdasarkan kearifan lokal ${ }^{6}$

2. Penataan batas kawasan Nino Coni Santana sesuai dengan peruntukannya

3. Pendanaan bagi perbaikan sarana dan prasarana di kawasan Nino Coni Santana perlu di tingkatkan

4. Sosialisasi bahaya pengelolaan lahan pertanian dengan tebas bakar di sekitar kawasan Nino Coni Santana.

5. Penguatan organisasi dengan pembentukan UPTD

6. Menggalang partisipasi masyarakat dalam penyelesaian penataan zonasi

\section{SIMPULAN DAN SARAN}

\subsection{Simpulan}

Pengelolaan Taman Nasional Nino Coni Santana harus berdasarkan kearifan lokal masyarakat Tutuala dan Mehara.Dalam rangka pengelolaan, penjagaan dan pelestarian Taman Nasional Nino Coni Santana, di perlukan penbentukan pengelolaan khusus.Diperlukan program pembinaan masyarakat dan kerja sama dengan masyarakat setempat dalam rangka pemanfaatan, pengawasan dan pengamanan Taman Nasional Nino Coni Santana.

\subsection{Saran}

1. Perlu memanfaatkan kearifan lokal sebagai basis pengelolaan Taman Nasional Nino Coni Santana dengan menciptakan hubungan yang harmonis dan sinergis antara pihak pengelola dengan tokoh-tokoh masyarakat dan pemerintah setempat.

2. Perlu menbentuk unit pengelolaan tingkat desa (UPTD) untuk pengelolaan Taman Nasional Nino Coni Santana dengan melibatkan stakeholder.

3. Sosialisasi berupa penyuluhan tentang pentingnya hutan perlu di tingkatkan, dengan peningkatan dan penberdayaan tenaga penyuluh lapangan. 
4. Untuk mengukur keberhasilan pengelolaan Taman Nasional Nino Coni Santana kedepan kegiatan monitoring, kontrol dan evaluasi secara transparan perlu dilakukan secara berkala oleh pemerintah dengan melibatkan masyarakat disekitar Taman nasional Nino Coni Santana.

\section{DAFTAR PUSTAKA}

Andrews, K R. 1980.The Concept of Corporate Strategy. Homewood. New York.

Awing. S. A. 2004. Dekonstruksi Sosial Foresty : Reposisi Masyarakat dan Keadilan Lingkungan. Bigraf Pub. \& Program Pustaka.Yogyakarta.

Daud, M. 2010. Upaya Meningkatkan Pembangunan Kehutanan di Indonesia. Fakultas Kehutanan. Universitas Hasanuddin. Makassar.
Peraturan pemerintah Republik Demokracia de Timor-Leste No. 8 tahun 2007 tentang kawasan Lindung.

Rangkuti, F. 2004. Analisis SWOT Teknik Membedah Kasus Bisnis.PT. Gramedia Pustaka Utama. Jakarta.

Undang-Undang (UU) 41 Tahun 1999. Tentang Kehutanan.

Wollenberg, Limbery G.Moeliono M.2009. Desentralisasi tata kelola hutan politik,ekonomi dan perjuangan untuk menguasai hutan di Kalimantan,center for Internasional Forestry research(UFOR) 